\title{
Getting closer to prostate cancer in patients - what scientists should want from clinicians
}

\author{
Norman J. Maitland \\ Cancer Research Unit, Department of Biology, University of York, Heslington, North Yorkshire YO10 5DD, UK.
}

Correspondence to: Dr. Norman J. Maitland, Cancer Research Unit, Department of Biology, University of York, Heslington, North Yorkshire YO10 5DD, UK. E-mail: n.j.maitland@york.ac.uk

How to cite this article: Maitland NJ. Getting closer to prostate cancer in patients - what scientists should want from clinicians. J Cancer Metastasis Treat 2017;3:262-70.

\section{Article history: \\ Received: 19 May 2017 \\ First Decision: 5 Jul 2017 \\ Revised: 13 Jul 2017 \\ Accepted: 14 Aug 2017 \\ Published: 17 Oct 2017}

\section{Key words:}

Prostate cancer treatments,

model systems,

primary cultures,

pre-clinical studies

\begin{abstract}
For scientists pursuing drug development for prostate cancer, it is critical that an appropriate ex vivo or in vitro model system is available for study. Cancer research has generally consisted of: (1) finding the means to arrest fast growing cancer cells; or (2) (as a compromise) to slow down the excessive rate of cell growth; or in the best case (3) to kill the cancer cells whilst sparing the surrounding normal tissues. As the knowledge of the biological nature of the cancer cell improves, it has become increasingly apparent that such a simplistic attitude to cancer therapy development or indeed diagnosis is rapidly outdated, and a closer liaison between the clinic and the laboratory studies is more important than ever as the author seeks to target specific gene expression pathways, specific signaling pathways, cancer specific mutations and indeed the interactions between cancer cells and their micro-environment, all of which provide a tremendous potential for novel therapeutic development.
\end{abstract}

\section{INTRODUCTION}

Not all cells within a cancer are fast growing. Indeed a proportion of cells within every tumor are probably quiescent and impervious to drugs targeting cell cycle activity ${ }^{[1,2]}$. To accommodate this cellular heterogeneity we really require new tissue mimetic cancer models ${ }^{[3]}$. For many scientists, the availability of "off the shelf" cancer cell lines is a facility which they use as a matter of expediency. The reasoning which makes a basic laboratory scientist choose a cancer model are: (1) robust cells which grow quickly (minimizing the amount of time required to do the experiment); (2) cells which are easy to infect or transfect; and (3) cells which express the gene or the signaling pathway of interest. In relatively few cases has any consideration been made of the stage of disease that a particular cell line represents. The study of "prostate cancer" is actually the study of a number of different diseases ${ }^{[4-8]}$, for example: (1) low Gleason grade tumors which have a weak capacity to invade; (2) high Gleason grade cancers which remain sensitive to the effect of male sex hormones but which are known to invade at least locally and

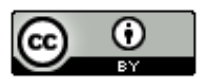

This is an open access article licensed under the terms of Creative Commons Attribution 4.0 International License (https://creativecommons.org/licenses/by/4.0/), which permits unrestricted use, distribution, and reproduction in any medium, as long as the original author is credited and the new creations are licensed under the identical terms.

For reprints contact: service@oaepublish.com

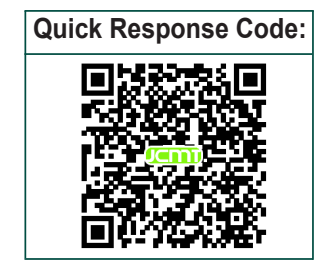


also have the capacity to spread at an early stage of the cancer; and (3) castration resistant disease (after hormone treatment) which has been shown in gene expression and mutational studies ${ }^{[9-11]}$ to represent a completely different type of cancer. Although castration-resistant prostate cancer shares some trunk or driver mutations ${ }^{[12]}$, it has developed a completely new mutation sub-set and ultimately the fatal lesion in prostate cancer, which often has a partly or wholly neuroendocrine phenotype and is impervious to most chemotherapy treatments ${ }^{[13,14]}$. To simply pick a cell line to represent "prostate cancer" is not sufficient, as is becoming increasingly apparent with our depth of analysis. If we now look back through the online scientific literature, which contains more than half a million references to LNCaP cells together with "prostate cancer treatment" in key words, one must begin to doubt the validity of many of these previous experiments.

There is also the question of timeliness. The castration resistant cancer of the 1980s was very different from that developed after the current generation of androgen therapies. For example, $\mathrm{LNCaP}$ was derived from a patient who had failed on the combination drug treatment of Estramustine (estrogen and nitrogen mustard, both hormone suppressive and strongly mutagenic) $)^{[15]}$.

\section{Origins of the LNCaP cell line}

The LNCaP cell line was derived (1977) from a 50 -year-old Caucasian male patient with stage D prostate cancer, and strong evidence of extraprostatic disease as determined by high serum levels of prostatic acid phosphatase ( $>20$ times normal). The patient had been treated with oral estrogens, orchiectomy and an aggressive course of estramustine chemotherapy. $\mathrm{He}$ also presented with metastases to the bone. At this point a biopsy from the supraclavicular lymph node was taken and cultured in RPMI medium containing $15 \%$ fetal calf serum and antibiotics. The cells grew rather slowly, although a single clone emerged with a population doubling time of $24 \mathrm{~h}$, known as the fast growing clone which is now supplied by the ATCC for research purposes.

The cells grow well (from a 107 cell inoculum) in immunocompromised mice to form poorly differentiated adenocarcinomas, and whilst tumor take is better in male compared to female mice, the rate of tumor growth is independent of the sex of the recipient mouse. No distal metastases are found with the parental line unless co-inoculated with fibroblast cells, although highly malignant sublines have subsequently been derived.
LNCaP cells have been in culture for more than 40 years with a hypotetraploid karyotype (84-87 chromosomes) and are genetically unstable. Both cell growth and secreted proteins (such as PSA) are sensitive in a biphasic manner to androgens, but also to estrogens, as the androgen receptor gene carries a mutation (T877A - selected/induced by the estrogenic/ mutagenic treatment of the patient?) which broadens the hormone binding capacity of the AR protein.

To overcome the latter property and to render LNCaP more sensitive to antiandrogen drugs, derivatives have been generated by transfection of extra copies of the AR gene (LNCaP-AR). AR low/negative (C4-2) and neuroendocrine derivatives can be readily generated by growth in selective media, specific gene knockout, and application of epigenetic modifiers such as histone deacetylase inhibitors.

It is therefore no surprise that the LNCaP genome is packed with secondary mutations, but also that $\mathrm{LNCaP}$ itself has a propensity to grow in estrogen supplemented medium. This is partly due to the original culture/xenografting procedure which is described in the original paper from $1980^{[15]}$, often forgotten by current day researchers, who simply treat it as an androgen responsive cell line.

\section{THE FUTURE: TEAM INTEGRATION AND STRATIFIED MEDICINE}

\section{The steep and downhill learning curves: beware of the next bandwagon}

When developing new anti-androgen receptor drugs, LNCaP has been the preclinical and basic science tool of choice. Given its responsiveness to estrogens and the presence of a mutant androgen receptor, this is perhaps surprising. To develop the new generation of androgen receptor inhibitors such as Enzalutamide, a variant of $\mathrm{LNCaP}$ into which extra copies of the androgen receptor gene (in an un-mutated wild type form) had been inserted, was used ${ }^{[16]}$. The consequences of extra androgen receptor expression within the cells appeared to make them especially sensitive to the anti-androgen drugs such as Enzalutamide. Does this represent a true reflection of the drug efficacy? It is somehow redesigning the test system to fit the drug. Whilst there is no doubt that Enzalutamide is a powerful and virtually irreversible inhibitor of androgen receptor in the clinic ${ }^{[17-21]}$, perhaps there are more complexities in real cancer tissues than seen in this now, increasingly artificial experimental cancer model. In our own experiments, LNCaP has proven to be hypersensitive to treatment by Docetaxel compared to every primary 


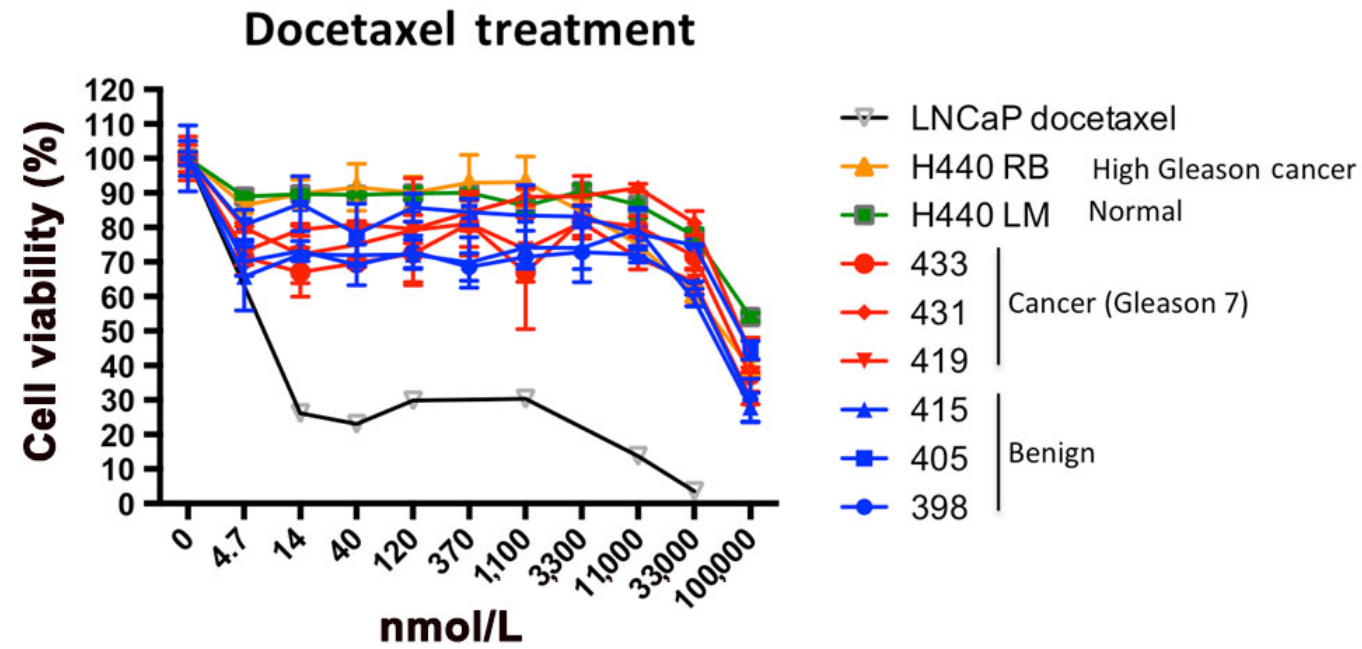

Figure 1: Response of primary patient cultures and the LNCaP cell line to docetaxel treatment. Cells were plated at 5,000 cells per well of 96 -well plates, treated with several doses of docetaxel and measured using alamar blue assay at $24 \mathrm{~h}$ post-treatment. Primary prostate epithelial cells cultured from patient samples from different disease grades and LNCaP cells were used (Data from Dr. Fiona Frame, University of York)

prostate culture, which we have treated with the same concentration of drug [Figure 1]. Unsurprisingly this is also true for a number of signaling pathway inhibitors, such as inhibition of Akt and PI3 Kinase. $\mathrm{LNCaP}$ is null for the PTEN gene, which renders the signaling pathways considerably more active. In most prostate cancer patients the situation is less clear cut with only very advanced prostate cancers having lost both copies of the PTEN gene. Most earlier stage cancers contain a single copy or express the PTEN protein at lower but still biologically active levels, a phenomenon known as haplo-insufficiency. In this case our experiments indicated that LNCaP has inactivated a number of emergency or salvage pathways during the 40 years in which LNCaP has been cultured on a nutrient rich medium of initially $15 \%$ and more recently $10 \%$ fetal calf serum. These pathways remain active in primary cancers ${ }^{[22]}$.

The final argument against designer cell lines is that of clonal selection. Prostate cancers are incredibly heterogeneous, containing multiple sub-clones with a restricted number of mutations, but with distinct differentiated states and epigenetic levels of control. To treat all of these with a single drug is over ambitious. However, to derive models such as those previously described, the scientist is reliant on the ability of some or all of these cancer cell types to grow in the laboratory. As a population of cells begins to grow from a cancer, those which initiate growth first are inevitably going to dominate the final culture by means of the exponential growth of cells. Exponential growth means that even within 3-4 days there could be 8 to 16 fold more of a fast growing cell compared to a slower growing cell in the same population. Thus long established cultures are sometimes representative only of the cells that will grow in the laboratory, which may not be the cells that grow quickly in the patient.

\section{Overcoming clonal bias}

Clearly the best method is to develop a closer liaison between clinicians working with patient samples and the scientists themselves. There are however a number of scientific arguments against this. Working with primary samples is time consuming and perceived to be prone to failure. To achieve statistical significance, ironing out the natural patient to patient variation in clinical samples, requires multiple samples far beyond the normal "journal requirements" (currently for at least 2 independent prostate cancer cell lines). How then should those representative cell lines be chosen? Are they selected because the results are consistent with the original hypothesis, or should they cover the same or different prostate cancer phenotypes? One sample each from castration resistant and hormone sensitive cells is by no means statistically significant, however the analysis of 10-12 tumors of a similar Gleason grade in patients with a similar hormone naïve background should provide statistically relevant results, which also can reflect, in their diversity, the patient specific variation we see in responses to many drugs ${ }^{[23]}$. Although clonal selection can also be an argument against primary cultures, they at least do have a heterogeneous phenotype (several cell subpopulations are represented), they can be differentiated in $2 \mathrm{D}$ culture to give rise to other, more luminal, cell populations and when routinely used at low passages the amount of time-dependent selection pressure is reduced. 


\section{Establishing a multidisciplinary team}

Thus truly translational research requires an ability to access fresh human cancer tissues, rather than employ the current laboratory "formula" for medical research, where detailed experiments are performed on cell lines, and then (often summarily) tested with a number of patient samples for the same response in formalin fixed tissue for antigen expression. Is this really valid as a critical assay of a longer term treatment for prostate cancers?

Certainly the availability of large numbers of tissue sections in array format should revolutionize the correlative part of such a study, but this resource is not available to all, and is of variable quality between different sources and centers depending on the time of surgery, fixation and processing required to produce a grid of perhaps 96 disease-focused tissue sections. It is also largely dependent on the skill of the histopathologist in obtaining the tumor localized blocks. When fresh unfixed tumor biopsies are required, this becomes just as much a multidisciplinary team effort as the treatment of prostate cancer. It involves the surgeon who removes the

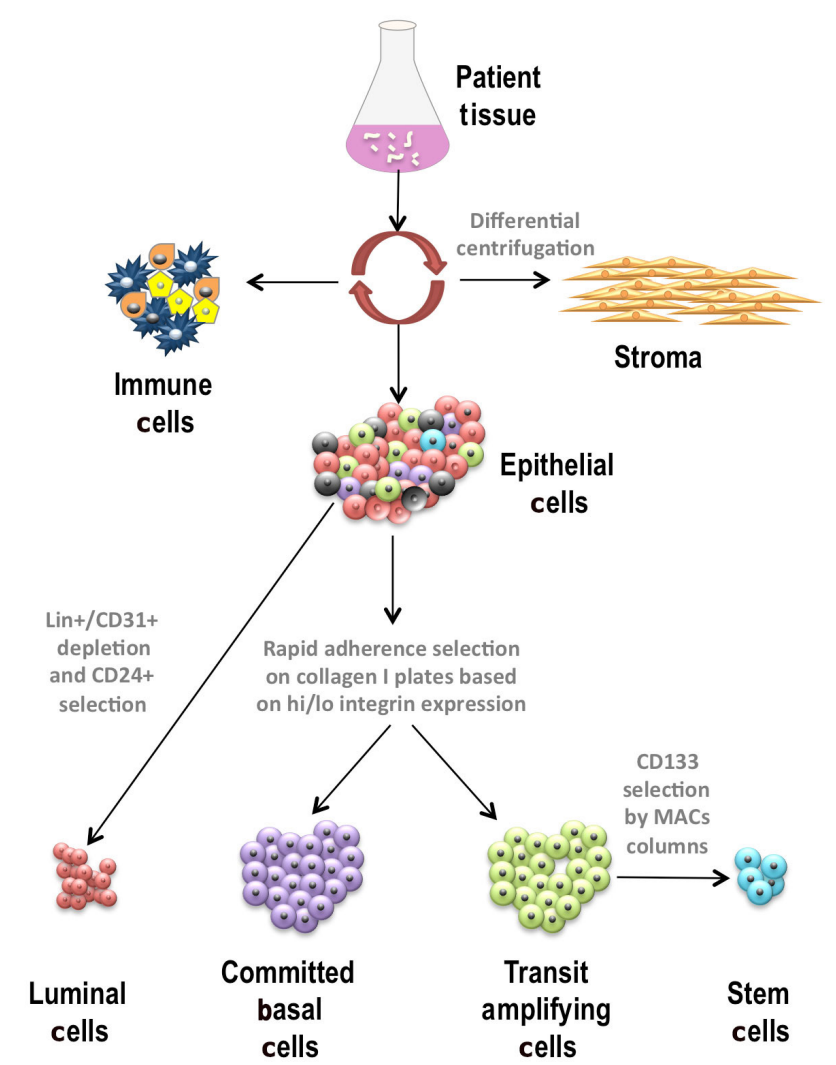

Figure 2: Selection of cells from prostate tissue. Protocols have been developed to extract, enrich and select different cell types from fresh human prostate tissue. The cell types include immune cells, stromal cells and epithelial cells. Luminal cells and basal cells, which include transit amplifying progenitor cells, committed basal cells and stem cells, can be selected biopsy, the pathologist who decides the area for sampling, the research nurse, technician or tissue procurement officer who takes the samples and finally the research team, who process and analyze the sample (see below). Finally the clinical history of the patient is required to ensure that a particular patient who has been studied intensively is not an anomaly within the general patient population, or indeed has been subject to an initial misdiagnosis.

In many cases, a basic science investigation does not fit within the National Health Service (NHS) ethical framework (and paperwork) in the UK, where the procedure is more often designed with a clinical trial of drug efficacy in patients, from whom tissue/blood samples are required. The elapsed time from application to approval is also rather long and incompatible with some grant deadlines. However, it remains essential to have such approval in place before funding is approved. Again the multidisciplinary team (MDT) approach and closer clinical science liaison is the best approach. Ethical compliance from the very start is not only desirable, but essential now for many grant-giving bodies.

\section{The complexities of tissue processing from tissue biopsies}

The next stage in the procedure involves the processing of the tissues from primary samples. Over many years my laboratory has developed the means to fractionate prostate tissues into many constituent cell types. This is illustrated in Figure 2. Although individual populations can for example be studied in isolation for a particular gene expression pattern or a cancer target expression, this may not be the ultimate analytical system in which to determine whether a patient's tumor is indeed susceptible to such treatment. The mere act of dissociating the tissue biopsy could be sufficient to modify gene expression in the short term. For example, the stress of homogenisation and the time taken may well affect individual gene expression patterns/cell types. The loss of infiltrating macrophages and lymphocytes from the tissues is also of concern, given our current knowledge of their influence on not only each other, but also on the whole tumor micro-environment.

Therapeutic development strategies which involve growing cells from prostate tissues in the laboratory are inevitably a compromise. Purification of different cell types and their culture removes micro-environmental influences. The mere induction of cell proliferation within a cell population also induces new patterns of gene expression, as we have recently shown in benign prostatic hyperplasia ${ }^{[24]}$. Such a reductionist approach 
is nevertheless useful and in the long term critical to determine treatment targets, in an easily controlled biological system. At the next level of complexity, the ability to co-culture multiple different populations from primary tissues offers something closer to the original patient, but is confounded by resolution of the individual cell types both during treatment and after treatment. Here the critical step has to be the inclusion of (1) a vehicle or non-treated control and (2) if possible a control of normal tissue from the same region of the prostate from the same patient. The latter remains a very rare occurrence in published accounts of experimental prostate cancer treatments, which often consist of a cancer cell line (or two) and one of the rare normal or non-malignant prostate cell lines (such as PNT2[ ${ }^{[25]}$ ) but more often involves a primary culture of "normal" prostate which can be purchased commercially ${ }^{[26]}$. Any scientist setting out on a similar experimental programme must remember that the culture media on which such primary cultures are maintained is often serum free and of a different calcium content to that required to culture the common prostate cells such as PC3, DU145 and LNCaP. How convincing would such a comparison be in another biological system when the effects of foetal calf serum in growth medium are also so manifold? The entire point of a defined culture medium has been to reduce the reliance on the "black box" effect of serum constituents - which often vary between suppliers, and indeed in batches from the same supplier.

The next level of complexity for treatment studies is the culture of tissue slices on artificial extra cellular matrix, or indeed on collagen sponges ${ }^{[27]}$. These have the added advantage of retaining haematological cell infiltrates, and include prostate stroma. However such studies can only be considered as "window" treatment studies over a short period of time. In our own studies of this system, the type of cell which proliferated within the tissue slice was critically dependent on the choice of growth medium. For example, in RPMI medium, growth of the stromal component was apparent whereas in higher calcium medium, the epithelial component would react. Supplementation of the culture medium with cholera toxin removed the stromal proliferation but ultimately resulted in tissue degeneration. A short period of time (3-7 days) is fine, but longer exposure/culture is likely to bias the final output. Tissue slicing strategies often also suffer from the stress imposed upon the tissues at the periphery of the sample. Thus only cells within the centre of the slice are credible candidates for treatment analyses as those on the outside are often too damaged and respond totally differently (as in a wound response) to be considered typical of the intact tissues.

\section{Compensation and redundancy in cell signaling}

The transmission of external stimuli to the nuclei of cancer cells has always been considered as a "pathway" by molecular biologists. A better description however is as a network or system. The naïve linear view of such signaling, for example when a growth factor binds to (one of) its receptors on the cell surface, has now been dispelled by current targeted inhibition studies. In a cell line, whose growth has become dependent on supplied growth factors, over perhaps a 20-year period of stress and adaptation in culture, such signaling networks have been degraded: what a cell does not require is frequently down-regulated, and even mutated - a situation which is more prevalent in advanced cancer cells and tissues with DNA replication and repair defects. Examples of the different drug sensitivities of multiple tissue derived cells, and the weak "model" provided by the industry standard LNCaP cells for this are shown in Figure 1. The same was true during the development of the now standard enzalutamide, as discussed earlier ${ }^{[16]}$.

The relevance of pathway intermediates can be approached by gene knockout (by CRISPR for example) or gene expression knockdown ( $\mathrm{Si}$ and ShRNA). Such techniques are readily applied to fast growing, clonogenic and easily transfected established cell lines, but their application in primary cultures of more clinical significance is substantially harder. In addition, the "clean" statistics from a couple of cell lines is not applicable in primary tissue-derived material. Primary cultures are often heterogenous (containing normal and malignant cells, as well as cells at different stages of differentiation), but there is also substantial inter-patient variability in the response to genetic manipulation. Therefore, sufficient numbers of patient samples are required to achieve a "consensus" view - if such an endpoint is actually achievable.

\section{The ideal clinical trial from a scientist's viewpoint}

The last statement brings me appropriately to the title and aim of the article. If we assume that the ultimate aim of translational research in cancers is to understand what happens in the patient, the MDT for cancer treatment now has to extend beyond the clinic to the scientific researchers. Back in 2010, I asked a genome sequencer, who was tracking oncogenic mutations in prostate cancer, what type of cancer their group needed for their studies. Expecting an answer of "high gleason grade", or "castrationresistant", or perhaps "a homogeneous mass", the reply was actually "a BIG one". Apparently the quality of material was less important, as the cellular 
composition could all be sorted out in the analysis - all that mattered was quantity. Of course we now know that many of these early next-generation RNA/DNA sequencing projects are confounded by cellular heterogeneity or by the unexpectedly high error rate in the sequencing itself $f^{[28]}$. Sequences of "model systems" reflect the enormous genetic drift (and selection) imposed by decades in cell culture. The quantities of nucleic acids required for the exercise are diminishing monthly: but there is still in my opinion insufficient control of homogeneity and quality. At this level, minor populations would be excluded and mutations in subpopulations perhaps missed altogether. Even single cell sequencing has the inherent bias introduced by comparison to a canonical genome or cancer cell expression pattern ${ }^{[29]}$. The individual cells that fail to match this can be excluded as abnormal, unrepresentative or even "normal". Cell calling will improve, but at present we are working with an imperfect resource, which I believe can only be solved by closer clinicalscientific collaboration.
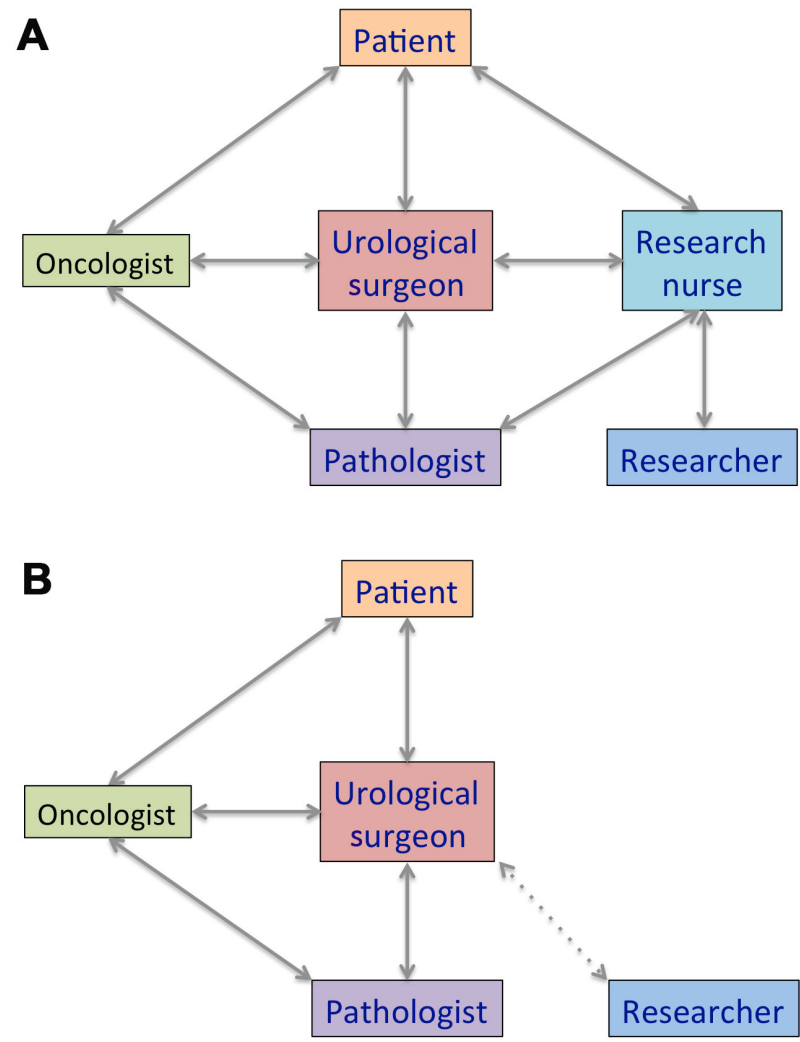

Figure 3: Components of the team required for a clinic to laboratory collaboration. (A) For a Lab-Clinic collaboration to work, collaboration and communication between several willing parties is required; $(B)$ one key member of staff is a research nurse or technician who can liaise between several different members of the team. Without this member, connection between the team members can be more challenging and there is more pressure on the urological surgeon
The perfect requirements for truly translational study of prostate cancer:

1. Provision of fresh human tissues. Most translational projects operate by "confirming" cell lines studies in arrays of archival and fixed human tissues. Perhaps a better model for study should be establishment of hypotheses in primary human tissues and subsequently confirming mechanisms in representative primary cells or cell lines.

Fresh human tissues impose a higher requirement for clinical-science cooperation. In our laboratory we have observed that, for some purposes, tissue which is more than $3 \mathrm{~h}$ from biopsy has significantly altered properties, and that storage overnight destroys most of the infiltrating lymphocytes, for example.

2. Transportation of tissues, apart from rapidity, requires a specialist medium. In some laboratories, an enriched cell culture medium containing high calcium and fetal calf serum is used. In addition, prevention of opportunistic infections can be almost eliminated by the presence of anti fungal and antibiotic agents. Transport medium should be relatively neutral and isotonic such as RPMI: to eliminate false growth and differentiation effects of calcium and calf serum. Rapid chilling to $4{ }^{\circ} \mathrm{C}$ is advantageous, but not always essential.

\section{Personnel: key members of a clinical team for translational research}

When establishing such a team I always stress that each member should do exactly what they are trained to do best [Figure 3]. However, it is important that by regular communication, the individual specialities should understand something of the procedures for obtaining and the subsequent analysis of tissuederived material. This feeds back to the key principle of co-authorship in ultimate publications in addition to obtaining ethical permission and design of the studies.

\section{The urological surgeon}

For benign, normal and organ confined or lymph node biopsies of tissues, the cooperation of the surgeon has been essential. The first priority should be to ensure patient wellbeing, and the provision of fresh tissues should not in any way compromise this. The presence of a research nurse or a junior surgical team member, who has been well briefed, is a major bonus for this procedure (see below) and in fact this person can act as the all-important bridge between the lab and the clinic.

We have also found it essential to plan ahead and to receive an operation list 1-2 weeks before surgery. 
Rather than take all tissues, we can then decide those which are required to be part of each specific scientific study. Prior warning is also important for provision of patient consent as part of our ethical requirements.

In this sense the surgeon is a vital part of the research team, although he may only feel that he is "supplying tissues". I prefer to refer to a surgeon's role as supplying first class tissue biopsies, and such a procedure is clearly worthy of an authorship on any scientific publications. The decision making, review of patient's details are all essential components in a translational study. As with all co-authors, the collaborating surgical team is sent final drafts (before submission) of relevant academic publications. They may claim not to understand all of the science, but hopefully can pick up on any clinical inaccuracies.

Lastly and perhaps most often neglected is the retention of strictly limited but anonymised clinical information about the patients not only prior to the first operation, but also over time - longer term clinical outcomes are essential when working on biomarkers, for example. Our collaborations have now been in place for a sufficient time to see the recurrence of tumors resected during the first periods of tissue collection: enabling longitudinal studies of tumor progression.

\section{Trainee surgeon or research nurse}

Such is the pressure on surgical time, the involvement of another team member radically boosts the quality (and quantity) of materials supplied to the research laboratory. There are two strategies possible, both of which involve the provision of part or full time salary, eligible to be funded by a scientific research grant.

Translational research has often been the result of the needs of a clinical trainee, who exploits the materials in his/her MD or PhD studies. Alternatively, funding a dedicated research "nurse" with an NHS or University employment contract can provide a service by taking postoperative biopsies (guided by the consulting histopathologist, see below). This person can also handle the shipping of materials in insulated packages. We also supply a dedicated refrigerator adjacent to the Operating Facility, which contains aliquoted transport media. The nurse/trainee liaises with both the laboratory and couriers to ensure rapid transfer for tissue processing.

Again this team member's importance goes beyond tissue provision. It begins by discussion of the research with the patient, when he is first scheduled for surgery. This not only involves supplying the required information sheets and forms for signature, but also the time to explain what will happen, including in our case withdrawal of 5-10 mL of venous blood. In our experience taking the time, and making personal contact ensures a high participation rate amongst patients, and their close relatives. The information provision is key both before and after surgery, and I strive to thank all of the contributing patients in any press releases and in journal paper acknowledgements. We are frequently asked on the regular visits to my laboratories by patient support groups, "Could that culture be from 'my' prostate cancer".

\section{Urological histopathology}

As discussed earlier in this review, there remains an enormous disconnection between the study of prostate cancer in a few cell lines, and the disease in real patients, as provided by histopathology analysis prior to surgery: decision making about treatment options. Where surgery is selected, then the analytical role of the pathologist does not end at this point. Firstly they must regularly review the post-operative biopsy procedure. Our intention is always to do nothing to harm the histological analysis, performed to confirm the initial biopsy based treatment decision. This secondary analysis can on occasion differ from the pre-operative one, and for scientific purposes it is really useful to both mark the research biopsy location (using inks) and/or to repair the sample location with a compatible glue filler. In both cases further analysis will confirm the precise section of tissue under scientific study - particularly important in a heterogeneous tumor such as prostate cancer.

Pathology also has a further role: to confirm that the patient matched "normal" tissue biopsies we take, when the tumor seems confined and relatively homogeneous, was indeed from a normal region of the prostate. For this approach to work, there is a certain amount of faith and extra effort from the science laboratory. On a number of occasions a normal or tumor biopsy has turned out to be incorrectly diagnosed, only after extensive processing [Figure 2] according to the histopathology analysis. The tissue is then relabeled, or even removed from the study as unreliable.

\section{Clinical and medical oncologists}

Once a prostate cancer patient has relapsed, or has chosen radiotherapy/brachytherapy, they are treated by oncologists. At this point a biopsy (from the patient rather than a post-operative specimen) is more difficult to justify ethically. However, this is the very population that we need to understand more - and to learn how to treat. We are now discovering that the application of chemotherapy/radiotherapy together with hormone treatment at an earlier stage in prostate cancer disease progression, provides startling 
improvements in survival. We will still be unable to determine which patients will benefit, without detailed longitudinal study of clinical tissues. Artificial cell line models of "progression" help little in this regard. I firmly believe that the future of cancer treatment lies in a patient/tumor-specific strategy, and without the clinical material to back this up, from both an early stage in the treatment cycle, and after the almost inevitable relapse, we are limiting our understanding of the disease. Every man appears to be different in his responses, although there are some overarching changes in response to therapy. The "fatal lesion" provided at rapid autopsy has been a goal of some major centers in the USA. This is an expensive exercise, which often lacks both pre-treatment normal tissues (chemotherapy affects all tissues in the patient, so a blood draw of lymphocytes from a patient after extensive chemotherapy will reflect the populations which survived the treatment) and the treatment naïve cancers as comparators. The depth of analysis of which we are now capable, simply demands better tissues to be used to their fullest capacity. It is these very tumor biopsies, which scientists really require from the oncology community, not just from patients referred to large research centers, but the "every prostate cancer patient" samples, from truly standard of care environments.

\section{CONCLUSION}

For almost 40 years, a limited set of established prostate cancer cell lines have dominated basic research in prostate cancers. Whilst they retain a number of key properties of the cancer in patients, they represent prostate cancer in an era before androgen therapies and targeted radiotherapy. In addition, the cells from LNCaP, DU145 and PC3 have been passaged repeatedly in different growth media and in immune-compromised mouse hosts. To study prostate cancer in the current decade we require models that represent contemporary disease.

By establishing a collaboration with the clinic, basic scientists can begin to ask the correct questions, whilst retaining the capacity to test mechanisms of action or hypotheses in appropriate established cell lines. However, we should be framing our hypotheses in actual cancers, either in human tissue biopsies or primary cell cultures (or both). Using multiple primary cultures or biopsies is the equivalent of an in vitro clinical trial for new drugs. Only by embracing the heterogeneity of the prostate cancer patient population can we begin to approach personalized, effective cancer medicine with an ultimate goal of long-term treatments for men with prostate cancer.

\section{DECLARATIONS}

\section{Authors' contributions}

N.J. Maitland contributed solely to the paper.

\section{Financial support and sponsorship}

I wish to acknowledge the ongoing support of my research in this area by grants from Prostate Cancer UK and Charity Soul.

\section{Conflicts of interest}

There are no conflicts of interest.

\section{Patient consent}

Not applicable.

\section{Ethics approval}

Not applicable.

\section{REFERENCES}

1. Chen W, Dong J, Haiech J, Kilhoffer MC, Zeniou M. Cancer stem cell quiescence and plasticity as major challenges in cancer therapy. Stem Cells Int 2016;2016:1740936.

2. Frame FM, Pellacani D, Collins AT, Simms MS, Mann VM, Jones GD, Meuth M, Bristow RG, Maitland NJ. HDAC inhibitor confers radiosensitivity to prostate stem-like cells. $\mathrm{Br} J$ Cancer 2013;109:3023-33.

3. MacRae EJ, Giannoudis A, Ryan R, Brown NJ, Hamdy FC, Maitland $\mathrm{N}$, Lewis CE. Gene therapy for prostate cancer: current strategies and new cell-based approaches. Prostate 2006;66:470-94.

4. Gleason DF. Classification of prostatic carcinomas. Cancer Chemother Rep 1966;50:125-8.

5. Epstein JI. An update of the Gleason grading system. J Urol 2010;183:433-40.

6. Epstein JI, Allsbrook WC Jr, Amin MB, Egevad LL; ISUP Grading Committee. The 2005 International Society of Urological Pathology (ISUP) Consensus Conference on Gleason grading of prostatic carcinoma. Am J Surg Pathol 2005;29:1228-42.

7. Gleason DF. Histologic grading of prostate cancer: a perspective. Hum Pathol 1992;23:273-9.

8. Gundem G, Van Loo P, Kremeyer B, Alexandrov LB, Tubio JM, Papaemmanuil E, Brewer DS, Kallio HM, Hognas G, Annala M, Kivinummi K, Goody V, Latimer C, O’Meara S, Dawson KJ, Isaacs W, Emmert-Buck MR, Nykter M, Foster C, Kote-Jarai Z, Easton D, Whitaker HC; ICGC Prostate Group, Neal DE, Cooper CS, Eeles RA, Visakorpi T, Campbell PJ, McDermott U, Wedge DC, Bova GS. The evolutionary history of lethal metastatic prostate cancer. Nature 2015;520:353-7.

9. Huang J, Wang JK, Sun Y. Molecular pathology of prostate cancer revealed by next-generation sequencing: opportunities for genomebased personalized therapy. Curr Opin Urol 2013;23:189-93.

10. Friedlander TW, Roy R, Tomlins SA, Ngo VT, Kobayashi Y, Azameera A, Rubin MA, Pienta KJ, Chinnaiyan A, Ittmann MM, Ryan CJ, Paris PL. Common structural and epigenetic changes in the genome of castration-resistant prostate cancer. Cancer Res 2012;72:616-25.

11. Wyatt AW, Gleave ME. Targeting the adaptive molecular landscape of castration-resistant prostate cancer. EMBO Mol Med 2015;7:878-94.

12. Lohr JG, Adalsteinsson VA, Cibulskis K, Choudhury AD, Rosenberg M, Cruz-Gordillo P, Francis JM, Zhang CZ, Shalek AK, Satija R, 
Trombetta JJ, Lu D, Tallapragada N, Tahirova N, Kim S, Blumenstiel B, Sougnez C, Lowe A, Wong B, Auclair D, Van Allen EM, Nakabayashi M, Lis RT, Lee GS, Li T, Chabot MS, Ly A, Taplin ME, Clancy TE, Loda M, Regev A, Meyerson M, Hahn WC, Kantoff PW, Golub TR, Getz G, Boehm JS, Love JC. Whole-exome sequencing of circulating tumor cells provides a window into metastatic prostate cancer. Nat Biotechnol 2014;32:479-84.

13. Beltran H, Rickman DS, Park K, Chae SS, Sboner A, MacDonald TY, Wang Y, Sheikh KL, Terry S, Tagawa ST, Dhir R, Nelson JB, de la Taille A, Allory Y, Gerstein MB, Perner S, Pienta KJ, Chinnaiyan AM, Wang Y, Collins CC, Gleave ME, Demichelis F, Nanus DM, Rubin MA. Molecular characterization of neuroendocrine prostate cancer and identification of new drug targets. Cancer Discov 2011;1:487-95.

14. Beltran H, Prandi D, Mosquera JM, Benelli M, Puca L, Cyrta J, Marotz C, Giannopoulou E, Chakravarthi BV, Varambally S, Tomlins SA, Nanus DM, Tagawa ST, Van Allen EM, Elemento O, Sboner A, Garraway LA, Rubin MA, Demichelis F. Divergent clonal evolution of castration-resistant neuroendocrine prostate cancer. Nat Med 2016;22:298-305

15. Horoszewicz JS, Leong SS, Chu TM, Wajsman ZL, Friedman M, Papsidero L, Kim U, Chai LS, Kakati S, Arya SK, Sandberg AA. The LNCaP cell line -- a new model for studies on human prostatic carcinoma. Prog Clin Biol Res 1980;37:115-32.

16. Tran C, Ouk S, Clegg NJ, Chen Y, Watson PA, Arora V, Wongvipat J, Smith-Jones PM, Yoo D, Kwon A, Wasielewska T, Welsbie D, Chen CD, Higano CS, Beer TM, Hung DT, Scher HI, Jung ME, Sawyers $\mathrm{CL}$. Development of a second-generation antiandrogen for treatment of advanced prostate cancer. Science 2009;324:787-90.

17. Saad F. Evidence for the efficacy of enzalutamide in postchemotherapy metastatic castrate-resistant prostate cancer. Ther Adv Urol 2013;5:201-10.

18. Merseburger AS, Haas GP, von Klot CA. An update on enzalutamide in the treatment of prostate cancer. Ther Adv Urol 2015;7:9-21.

19. Cicero G, DE Luca R, Dorangricchia P, Dieli F. The clinical efficacy of enzalutamide in metastatic prostate cancer: prospective singlecenter study. Anticancer Res 2017;37:1475-80.

20. Scher HI, Beer TM, Higano CS, Anand A, Taplin ME, Efstathiou E, Rathkopf D, Shelkey J, Yu EY, Alumkal J, Hung D, Hirmand M, Seely
L, Morris MJ, Danila DC, Humm J, Larson S, Fleisher M, Sawyers CL; Prostate Cancer Foundation/Department of Defense Prostate Cancer Clinical Trials Consortium. Antitumour activity of MDV3100 in castration-resistant prostate cancer: a phase 1-2 study. Lancet 2010;375:1437-46.

21. Higano CS, Beer TM, Taplin ME, Efstathiou E, Hirmand M, Forer D, Scher HI. Long-term safety and antitumor activity in the phase 1-2 study of enzalutamide in pre- and post-docetaxel castration-resistant prostate cancer. Eur Urol 2015;68:795-801.

22. Butler DE, Marlein C, Walker HF, Frame FM, Mann VM, Simms MS, Davies BR, Collins AT, Maitland NJ. Inhibition of the PI3K/AKT/ mTOR pathway activates autophagy and compensatory Ras/Raf/ MEK/ERK signalling in prostate cancer. Oncotarget 2017;8:56698713.

23. Ulukaya E, Frame FM, Cevatemre B, Pellacani D, Walker H, Mann VM, Simms MS, Stower MJ, Yilmaz VT, Maitland NJ. Differential cytotoxic activity of a novel palladium-based compound on prostate cell lines, primary prostate epithelial cells and prostate stem cells. PLoS One 2013;8:e64278.

24. Rane JK, Droop AP, Maitland NJ. A detailed analysis of gene expression in human basal, luminal, and stromal cell populations from benign prostatic hyperplasia tissues and comparisons with cultured basal cells. Eur Urol 2017;72:157-9.

25. Berthon P, Cussenot O, Hopwood L, Leduc A, Maitland N. Functional expression of sv40 in normal human prostatic epithelial and fibroblastic cells - differentiation pattern of nontumorigenic cell-lines. Int J Oncol 1995;6:333-43.

26. Sobel RE, Wang Y, Sadar MD. Molecular analysis and characterization of PrEC, commercially available prostate epithelial cells. In Vitro Cell Dev Biol Anim 2006;42:33-9.

27. Centenera MM, Raj GV, Knudsen KE, Tilley WD, Butler LM. Ex vivo culture of human prostate tissue and drug development. Nat Rev Urol 2013;10:483-7.

28. Fox EJ, Reid-Bayliss KS, Emond MJ, Loeb LA. Accuracy of next generation sequencing platforms. Next Gener Seq Appl 2014;1: pii: 1000106.

29. Gawad C, Koh W, Quake SR. Single-cell genome sequencing: current state of the science. Nat Rev Genet 2016;17:175-88. 